\title{
A política de incentivos fiscais em Santa Catarina: lobby político, poder econômico e desigualdades regionais
}

\author{
The fiscal incentives policy in Santa Catarina: political lobby, economic power \\ and regional inequalities
}

\author{
Juliano Giassi Goularti*
}

\begin{abstract}
Resumo: Este artigo trata de analisar a política de incentivos fiscais do Imposto sobre Operações Relativas à Circulação de Mercadorias e sobre Prestações de Serviços de Transporte Interestadual, Intermunicipal e de Comunicação (ICMS) em Santa Catarina. Para isso, escapa da narrativa do pensamento comum de que a renúncia do imposto estadual é condição sine qua non para a formalização do mercado de trabalho. Nessa linha de entendimento, o artigo se propõe a constituir uma categoria analítica para definir e analisar a contradição da política de incentivos fiscais do ICMS. Ao mesmo tempo, busca problematizar a relação da isenção do imposto com a política de desenvolvimento regional. Com isso, almeja contribuir para as análises e estudos da política de incentivos fiscais em Santa Catarina, haja vista a existência de poucos trabalhos publicados sobre o tema, quanto mais sob uma perspectiva crítica social.
\end{abstract}

Palavras-chave: Macroestrutura fiscal; ICMS; Santa Catarina

\begin{abstract}
This article analyzes the fiscal incentive policy of the Tax on Operations Relative to the Circulation of Goods and on the Provision of Interstate, Intermunicipal and Communication Services (ICMS) in Santa Catarina. For this, it goes beyond the common sense that the renunciation of the state tax is a sine qua non condition for the formalization of the labor market. In this line of understanding, the article proposes to constitute an analytical category to define and analyze the contradiction of the ICMS tax incentive policy. At the same time, it seeks to problematize the relationship between tax exemption and regional development policy. According to this, it aims to contribute to the analysis and studies of fiscal incentives policy in Santa Catarina, given the existence of few published works on the subject, let alone from a critical social perspective.
\end{abstract}

Keywords: Fiscal macro framework; ICMS; Santa Catarina

JEL Code: E62; H71

\footnotetext{
*Doutor pelo Instituto de Economia da Unicamp. E-mail: jggoularti@gmail.com.
} 


\section{Introdução}

Os tributos, o Estado e o orçamento público andam juntos há séculos. Para financiar suas atividades, o Estado necessita de recursos que são arrecadados dos diversos segmentos da sociedade. A capacidade do Estado de tributar e isentar de tributos a sociedade depende das correlações de força que governam a economia e a política. O tamanho do Estado e a forma de financiá-lo é uma construção histórica: quem deve pagar mais impostos, quem deve pagar menos, quem não deve pagar, quem se apropria mais ou menos e qual a extensão da atuação estatal em cada país.

Isso posto, o objetivo deste artigo é analisar a política de incentivos fiscais do governo do Estado de Santa Catarina, em particular referente ao Imposto sobre Operações Relativas à Circulação de Mercadorias e sobre Prestações de Serviços de Transporte Interestadual, Intermunicipal e de Comunicação (ICMS). O texto não se propõe a fazer uma análise geral da política econômica nacional e estadual nem discutir as correntes teóricas no campo da política fiscal. Para isso, recomenda-se a tese de livre docência do professor Lopreato (2013) e a dissertação de mestrado de Goularti (2014), ambas transformadas em livro.

O objetivo do artigo é ao mesmo tempo amplo e circunscrito. Trata-se de um objeto amplo pois envolve categorizar a constituição de uma macroestrutura fiscal do ICMS que remete à totalidade das modalidades de isenções, e circunscrito porque considera que esta temática é desenvolvida de maneira preliminar e periférica pelos economistas catarinenses. Como hipótese de pesquisa, o fator constitutivo (primeiro plano) da macroestrutura fiscal do ICMS é a redução de custo de produção e a elevação da taxa de lucro do capitalista. Dito de outra forma, as isenções substituem a incapacidade do mercado de realizar as condições gerais para a reprodução do capital. Como retórica empresarial e fator subjetivo (segundo plano), o benefício fiscal do imposto estadual é narrativa para a formalização do mercado de trabalho e geração de renda.

Partindo do esforço crítico, o texto escapa da narrativa do "pensamento único", expressão cunhada por Arthur Schopenhauer para definir o pensamento que se sustenta a si mesmo. Por isso, renuncia-se à ideia de que a isenção do imposto estadual é condição sine qua non para a formalização do mercado de trabalho, retórica utilizada pelo lobby político para manter os privilégios fiscais. Diante disso, podemos considerar as múltiplas estruturas fiscais do ICMS que 
constituem a macroestrutura como sinônimo automático de desenvolvimento econômico e social? Eis aqui a problemática do trabalho.

Entre os métodos de pesquisa, destaca-se a documentação indireta, que abrange a pesquisa documental e bibliográfica. A pesquisa documental é necessária por implicar a possibilidade de contato com planos e relatórios oficiais. A bibliográfica complementa a documental na medida em que atualiza os diversos argumentos sobre o tema examinado. Para construção deste estudo, dispomos de um conjunto de dados e informações que foram pesquisados em livros e relatórios disponibilizados pela Secretaria de Estado da Fazenda (SEF/SC), pelo Tribunal de Contas (TCE/SC), pelo Ministério Público (MP/SC) e pela Assembleia Legislativa de Santa Catarina (ALESC).

Nessa linha, o trabalho está subdividido em quatro partes, além da introdução e das considerações finais. A primeira trata de constituir uma categoria analítica para definir e analisar a dinâmica contraditória da política de incentivos fiscais do ICMS. A segunda retrata o lobby político de grupos empresariais pela manutenção e ampliação das isenções que formam a macroestrutura fiscal do ICMS. A terceira problematiza a relação da macroestrutura com a política de desenvolvimento regional, e a quarta concentra-se em desmistificar a noção de que isenção é sinônimo de emprego e renda.

Por fim, almeja-se que esta pesquisa possa contribuir para as análises e estudos da política de incentivos fiscais em Santa Catarina, haja vista a existência de poucos trabalhos publicados acerca do tema, quanto mais sob uma perspectiva crítica social.

\section{Macroestrutura fiscal: uma categoria analítica da política de incentivos fiscais em Santa Catarina}

À primeira vista, a análise da política de incentivos fiscais é interpretada como sinônimo do processo de desenvolvimento econômico. Partindo desse ponto, os incentivos - anistia, remissão, subsídio, crédito presumido, isenção, alteração de alíquota ou modificação da base de cálculo, dentre outros benefícios ${ }^{1}$ representam as necessidades determinadas pela dinâmica da acumulação

\footnotetext{
${ }^{1}$ Quanto a isso, a conceituação proposta por Henriques (2009) distingue, de um lado, as expressões sinônimas benefício fiscal, benefício tributário, incentivo fiscal e, de outro, os termos equivalentes renúncia de receita, renúncia fiscal (tax expenditure, como designado na literatura internacional) e gasto tributário.
} 
capitalista. Em outras palavras, trata-se de um instrumento público colocado à disposição do privado para redução de custos de produção e formação da taxa de lucro.

Dito de outro modo, os incentivos do ICMS procuram compensar a iniciativa privada dos riscos do desenvolvimento econômico, fazendo a sociedade participar também do custo deste projeto. De antemão, é contribuinte do ICMS qualquer pessoa física ou jurídica que realize, com habitualidade ou em volume que caracterize intuito comercial, operações de circulação de mercadoria ou prestações de serviços de transporte interestadual e intermunicipal e de comunicação, ainda que as operações e as prestações se iniciem no exterior. Portanto, a arrecadação do imposto estadual ocorre pela intervenção do Estado na atividade econômica que gera circulação e prestação de serviços, nos quais podem ser distinguidas as despesas de investimento e de custeio ou de consumo.

Desde a sua constituição, o incentivo concedido pelo Estado de Santa Catarina beneficiou três setores de atividade: indústria, comércio e agricultura. Da mesma forma, esses setores foram se habilitando com o Estado para receber o benefício, deixando, assim, de recolher parcialmente o imposto devido. Portanto, o incentivo fiscal que está fracionado em múltiplos programas e modalidades vem, ao longo dos anos, propiciando aos setores de atividade, independentemente de seu tamanho, abrangência e ramo, condições fiscais para que possam se ampliar e valorizar-se no mercado. Como resultado disso, em 2018, os incentivos fiscais do ICMS somaram R $\$ 5,80$ bilhões, representando 38,10\% da arrecadação do referido imposto e 21,91\% da receita orçamentária (TCE, 2019).

Assim sendo, as múltiplas estruturas fiscais que constituem renúncia de receita do $\mathrm{ICMS}^{2}$ formam uma macroestrutura fiscal. Nos termos aqui retratados, a macroestrutura é uma construção histórica do desdobramento do desenvolvimento do capitalismo e das formas de organização do capital. A macroestrutura fiscal se dá no sentido de englobar a totalidade dos mais distintos modos de financiar a acumulação de capitais. Ainda sobre a macroestrutura fiscal, ela não deve ser encarada como um mero programa ou modalidade de incentivo

\footnotetext{
${ }^{2}$ Nos moldes do art. n. ${ }^{\circ} 14$ da Lei de Responsabilidade Fiscal, a renúncia de receita consiste na concessão, prorrogação ou ampliação de anistia, remissão, subsídio de natureza tributária, financeira, ou creditícia, crédito presumido, isenção em caráter não geral, redução discriminada de alíquota ou de base de cálculo relativa a impostos, taxas ou contribuições, e outros benefícios que correspondam a tratamento diferenciado.
} 
setorial ou regional, mas como resultado das múltiplas estruturas fiscais que constituem a isenção do ICMS, isenções que se articulam em redes de forma integrada, autônoma e independente. Mesmo com níveis de diferenciação, se "o todo sem a parte não é todo" e "a parte sem o todo não é parte", como nos ensinou sábia e ironicamente o poeta Gregório de Matos, as múltiplas estruturas do ICMS são a parte do processo, com suas especificidades próprias, e o todo é a macroestrutura fiscal, posto que ambas integram a mesma totalidade. Para tanto, o todo representa uma força maior do que a soma das partes de seus elementos concebidos isoladamente.

Partindo dessa compreensão, o que se entende por macroestrutura é a totalidade orgânica dessas estruturas fiscais distribuídas em diversos programas (Prodec, Pró-Emprego, Pró-Náutica, Pró-Cargas, dentre outros) e modalidades (isenção, anistia, benefício, crédito presumido, remissão, dentre outros) que estimulam conflitos e contradições no interior da dinâmica capitalista. O que se está chamando de macroestrutura fiscal não é aqui usado para designar ou mesmo classificar uma configuração no plano das relações políticas e econômicas. Tratase de abstrair da história uma categoria explicativa que só tem sentido dentro do contexto histórico que condiz com a totalidade dos programas de incentivos fiscais. Essa categoria aponta para a necessidade de um esforço de analisar sistematicamente a política de incentivos fiscais cujos mais variados programas fiscais se articulam com a economia, representando não a parte, mas a totalidade de um movimento maior, o movimento da acumulação.

A categoria ora constituída trata de enriquecer a análise da política fiscal de desoneração. Cada uma dessas múltiplas estruturas do ICMS representa uma rede integrada de processos econômicos e relações políticas que, de um lado, tem uma dinâmica própria em se relacionar com a acumulação e, de outro, uma fusão que forma uma macroestrutura com caráter orgânico capaz de permitir a expansão do capitalismo. Essas estruturais fiscais se articulam formando a macroestrutura fiscal. Logo, a formação de uma macroestrutura fiscal capitalista a partir do desenvolvimento do capitalismo é um sistema com múltiplas estruturas movido por interesses econômicos e lobbies políticos dentro das instituições estatais de poder (Executivo, Legislativo e Judiciário).

Com tal perspectiva, este artigo desenvolve a ideia de que a macroestrutura fiscal é um instrumento utilizado para dar garantias da reprodução dos negócios 
realizados pelo capital. Dessa forma, quando o Estado anuncia ao mercado a existência da macroestrutura fiscal, está revelando sua existência e os interesses na preservação do valor, uma vez que ela é uma das formas de preservação e reprodução da produção de mercadorias. Nessas condições, a formação de uma macroestrutura leva a uma perda relativa do monopólio do sistema de crédito, até porque as vigências dos juros altos e as variações do câmbio encarecem e escasseiam o crédito bancário, além de aumentarem os custos financeiros das empresas.

A categoria macroestrutura fiscal apresenta um caráter sistêmico, pois diz respeito ao modo como se dá o processo histórico de evolução e transformação da política fiscal do ICMS no Estado de Santa Catarina. Portanto, é necessário que a classe dirigente dos interesses do capital ocupe diretamente postos (Secretarias, Diretorias, Agências, Cargos de Confiança, etc.) de tomadas de decisão dentro da máquina estatal que influenciem a política fiscal a exercer as vontades e necessidades dos capitalistas. Nesse sentido, de uma parte, a macroestrutura fiscal oferta condições de financiamento fiscal para o desenvolvimento do capital; de outra, constitui uma forma de exploração do recurso público, extraído de maneira regressiva.

Há ainda outro aspecto digno de análise. As múltiplas estruturas fiscais do ICMS que constituem a macroestrutura fiscal manifestam-se conforme a correlação de forças da categoria luta de classe. Tendo por base essa categoria analítica, quem paga mais e quem paga menos impostos, e quem se apropria mais ou menos dos incentivos fiscais são disputas que se dão no campo da política e das relações econômicas. Logicamente, se existem classe que se beneficiam consideravelmente da macroestrutura fiscal, há outras que são prejudicadas. A classe menos favorecida, os trabalhadores, ao mesmo tempo que são os que pagam a maior parcela dos tributos pelo sistema tributário regressivo, são os que menos se apropriam das desonerações fiscais.

Todavia, é interessante explicar que as diferentes estruturas fiscais do ICMS que formam a macroestrutura estão em constante movimento quantitativo e qualitativo, seja o movimento de incorporar um novo setor econômico, privilegiar certa região em detrimento de outra, priorizar isenção ou redução de base de cálculo ou ainda conceder crédito presumido ou dar prioridade dos incentivos para os pequenos e médios negócios em relação à grande indústria. Ademais, as 
decisões de beneficiar este ou aquele setor, região e classe derivam de uma decisão política determinada pelo poder e grupos econômicos.

\section{O lobby político e os incentivos fiscais em Santa Catarina}

Desde o nascimento da economia como ciência autônoma do conhecimento, a formação da riqueza é centro de investigações por parte dos economistas das diferentes vertentes teóricas e ideológicas. Quanto a essa questão, há um profícuo debate sobre a origem, a causa, a geração, a distribuição, o ciclo (prosperidade/instabilidade, estabilidade) e a reprodução da riqueza social. Ao longo do tempo histórico, multiplicaram-se a forma de realização da acumulação e do valor. Nesses termos, temos um processo de metamorfose da riqueza no qual a política de incentivo fiscal do ICMS, por intermédio da constituição da macroestrutura, constitui uma parte dessa totalidade.

Nos últimos anos, o debate sobre a política de incentivos fiscais ocupou espaço cada vez maior na mídia social, na academia, na ALESC e no TCE/SC. A razão disso é decorrente da expansão desenfreada dos incentivos do ICMS e da guerra fiscal. Num âmbito de incerteza que corresponde aos objetivos da valorização dos capitais, as decisões empresariais se lançam a reduzir riscos. O incentivo usufruído pelo capital pode não se converter em investimento privado, ficando retido porque o lucro derivado do investimento é incerto. Mesmo assim, utilizando a isenção do ICMS para investir ou não, o incentivo fiscal é um componente que constitui a formação da taxa de lucro.

$\mathrm{Na}$ análise do objeto de estudo, a macroestrutura fiscal é um sistema complexo de incentivos fiscais do ICMS por oferecer múltiplas estruturas de isenção do imposto. Para tanto, considerando que a burguesia catarinense (e nacional) é economicamente incapaz de criar uma indústria forte, diversificada e complexa, com capitais parcos, pulverizados e incompatíveis com a grande indústria e com suas exigências financeiras, pela via fiscal (e financeira) o governo estadual assumiu a tarefa de sujeito do processo, levando a cabo o projeto de desenvolvimento econômico e industrial (GOULARTI, 2014).

Dentro do movimento da política estadual de incentivo fiscal, é oportuno trazer à tona que parte expressiva da renúncia fiscal do ICMS concedida pelo governo catarinense é direcionada para o capital multinacional, isto é, a água 
mineral Imperatriz, de Santo Amaro da Imperatriz/SC, possui o mesmo benefício que a água mineral VOSS, da Noruega. O Arroz Fumacense, de Morro da Fumaça/SC, possui o mesmo benefício que o arroz japonês Tipo 1 Guin, e o macarrão Isabela, de São José/SC, tem a mesma isenção que o macarrão Barilla, da Itália. Duas observações: i) dentro de um sistema tributário regressivo, a renúncia de receita de impostos do ICMS sobre mercadorias consumidas exclusivamente pela classe média e alta, devido ao seu poder de compra, se dá sobre o a classe trabalhadora; e, ii) as isenções são parte do lucro das multinacionais remetido à matriz com isenção de remessa por meio da Lei Federal n. ${ }^{\circ} 9.249 / 1995 .^{3}$

A partir dessa incapacidade de aglutinar capitais, o Estado de Santa Catarina, mediante a renúncia do imposto, em particular do ICMS, propicia a mobilização de recursos socialmente necessários para realização do investimento pela intermediação da política fisscal. De forma direta e explícita, desde a criação do Fundo de Desenvolvimento de Santa Catarina (Fundesc), em 1963, a política de incentivos executada pelo governo estadual tratou de fornecer recursos para o setor industrial, comercial e agroindustrial para fins do progresso técnico. De lá para cá, foram constituídas múltiplas estruturas fiscais que correspondem a distintas linhas de financiamento nas quais se processam as decisões capitalistas, ao mesmo tempo que são um impulso para ampliar a acumulação interna de lucros.

Com a Lei de Responsabilidade Fiscal (LRF), em 2000, a renúncia de receita passou a compor o anexo de metas fiscais da Lei de Diretrizes Orçamentárias (LDO). Com isso, a apuração dos valores renunciados para fins de desenvolvimento do Estado passou a ser publicada em lei específica. Até então era possível apurar os valores renunciados apenas pelo Programa Especial de Apoio à Capitalização de Empresas (Procape), extinto em 1984, e pelo Programa de Desenvolvimento da Empresa Catarinense (Prodec), em vigor. A LRF deu maior transparência, porém não foram estabelecidos (nem pela LDO) mecanismos de fiscalização e monitoramento das múltiplas modalidades de incentivos concedidos ao setor privado pela macroestrutura fiscal do ICMS.

\footnotetext{
${ }^{3}$ Temos aqui um caso de dupla isenção. A isenção do imposto estadual do ICMS eleva a margem de lucro da empresa multinacional (filial) que faz a remessa de lucros e dividendos (matriz) no exterior com isenção do imposto federal.
} 
No movimento da guerra fiscal entre as Unidades da Federação, o governo catarinense passou a conceder benefícios sem a aprovação do Conselho de Política Fazendária (Confaz). Além disso, muitos dos benefícios regulamentados pelo Anexo II da Lei n. ${ }^{\circ}$ 10.297/1996 passaram a ser concedidos por decreto, ou mesmo por contratos de "gaveta", ignorando o dispositivo constitucional. Para mais, os Convênios aprovados no âmbito do Confaz, do qual Santa Catarina é signatária, eram homologados pela Assembleia Legislativa. Stricto sensu, a homologação tácita daria maior agilidade na concessão do incentivo, evitando-se, deste modo, “entraves desnecessários" para a realização dos Convênios (MP/SC, 2017).

Aqui, macroestrutura fiscal do ICMS constitui um plano da concorrência que firmas/indústrias/empresas praticam para aniquilar seu rival mais próximo. Nela, os grandes capitais, em detrimento dos pequenos, praticam dumping ao se credenciar em uma das múltiplas estruturas fiscais que formam a macroestrutura, haja vista que a possibilidade de uma grande empresa se capacitar burocrática, técnica e financeiramente em relação à pequena empresa é muito superior. Uma vez tendo se apropriado do incentivo pela prática de dumping, o movimento do grande capital trata de alijar os pequenos capitais. A isenção do imposto é um instrumento de acumulação que o capital nacional e multinacional utiliza para se valorizar, embora essa acumulação e valorização jamais chegassem à vista da maioria da população catarinense.

Com a guerra fiscal, a macroestrutura fiscal do ICMS passou a ser utilizada com maior exaustão para a atração de novos investimentos e para a preservação daqueles já realizados no Estado. Num mundo globalizado pelas cadeias globais de valor, os estados, as regiões e cidades são chamados a competir. Dessa forma, a concessão de incentivos pelas múltiplas estruturas fiscais do ICMS por parte do governo catarinense generalizou-se, passando de $\mathrm{R} \$ 565$ milhões, em 2002, para $\mathrm{R} \$ 5,92$ bilhões em 2019. Registra-se ainda um crescimento da renúncia fiscal per capita, de $\mathrm{R} \$ 467,14$, em 2008, para R $\$ 818,42$, em 2018. Hoje são 11.145 empresas que não recolhem ICMS, $80 \%$ da arrecadação estadual. Ainda, os benefícios concedidos pela Fazenda Estadual, sem autorização da ALESC, somam mais de 30 mil páginas (ALESC, 2019c). 
Tabela 1 - Lei de Diretrizes Orçamentárias (LDO) - Santa Catarina (R\$ milhões, preço constantes)

\begin{tabular}{cr}
\hline LDO & Renúncia tributária (ICMS, IPVA e ITCMD) \\
\hline LDO/2002 (PL./106.3/2001) & 565 \\
LDO/2003 (PL./177.3/2002) & 613 \\
LDO/2004 (PL./62.4/2003) & 718 \\
LDO/2005 (PL./165.0/2004) & 805 \\
LDO/2006 (PL./105.9/2005) & 1.001 \\
LDO/2007 (PL./163.8/2006) & 2.096 \\
LDO/2008 (PL./104.8/2007) & 2.308 \\
LDO/2009 (PL./102.6/2008) & 2.827 \\
LDO/2010 (PL./106.0/2009) & 3.006 \\
LDO/2011 (PL./119.4/2010) & 4.272 \\
LDO/2012 (PL./140.1/2011) & 4.873 \\
LDO/2013 (PL./146.7/2012) & 4.666 \\
LDO/2014 (PL./104.8/2013) & 5.015 \\
LDO/2015 (PL./105.9/2014) & 5.179 \\
LDO/2016 (PL./110.6/2015) & 5.455 \\
LDO/2017 (PL./110.6/2016) & 5.578 \\
LDO/2018 (PL./103.7/2017) & 5.803 \\
LDO/2019 (PL./97.4/2018) & 5.928 \\
LDO/2020 (PL./89.4/2019) & 5.535 \\
\hline
\end{tabular}

Fonte: LDO, vários anos. Elaboração do autor.

A receita pública, composta principalmente por tributos, é fundamental para o desenvolvimento econômico, social e cultural do Estado. Todo um conjunto de serviços - segurança, educação, saúde, previdência e assistência social, transporte e comunicações, entre outros - depende, em larga medida, da ação do Estado. Ressalte-se que o recurso renunciado pela macroestrutura fiscal do ICMS, em 2018 , é superior aos gastos com saúde ( $\mathrm{R} \$ 2,82$ bilhões) e educação ( $\mathrm{R} \$ 4,91$ bilhões). Cumpre destacar que muitas das propostas publicadas por decreto e lei específica não são acompanhadas de demonstrativo da estimativa do impacto orçamentário e financeiro na concessão do benefício, conforme prevê a LRF. Como exemplo, pode-se citar os Projetos de Lei n. ${ }^{\circ} 28.2 / 2019$, n. $^{\circ} 29.3 / 2019$, n. $^{\circ}$ 55.5/2019, n. ${ }^{\circ} 81.7 / 2019$, n. $^{\circ} 170.7 / 2109$ e n. ${ }^{\circ}$ 174.0/2019 enviados à ALESC pelo governador Carlos Moisés, do PSL.

As contínuas mudanças na legislação, aumentando a quantidade e prorrogando prazos de setores beneficiados, assim como o impacto nas contas 
públicas, deixou a política de isenção do ICMS em destaque. Nesse quesito, o lobby político utiliza da prerrogativa de que a isenção do imposto é condição para fortalecer a economia estadual, buscando promover a ampliação da capacidade competitiva das empresas radicadas no Estado no cenário nacional e internacional, fomentar a inovação, garantir emprego e gerar renda aos trabalhadores. Quando há uma discussão para rever benefícios da macroestrutura, estabelecendo limites para uma redução gradual da renúncia fiscal, empresários, trabalhadores e o poder econômico do capital entram em campo. Uma das justificativas para a manutenção dos incentivos é de que com eles as exportações de US\$ 6 bilhões, em 2006, saltaram para US\$ 9 bilhões, em 2019. Por outro lado, o déficit comercial passou de US\$264,03 milhões, em 2009, para US\$ 6,2 bilhões, em 2019 (FIESC, 2019).

Em 27 de dezembro de 2018, o governo do Estado publicou o Decreto n. ${ }^{\circ}$ 1.866, revogando benefícios fiscais das grandes corporações multinacionais que controlam a produção de agrotóxico. Com esse decreto, seriam reduzidos substancialmente os incentivos fiscais de produtos que causam danos ao meio ambiente, como os agrotóxicos. Na ocasião, passaria a valer em Santa Catarina a chamada "Tributação Verde". Produtos como inseticidas, fungicidas, formicidas, herbicidas, raticidas e outros agrotóxicos isentos do pagamento de ICMS passariam a estar sujeitos a uma alíquota de 17\%. Naquele momento, foram revogadas as isenções do ICMS do Gás Liquefeito de Petróleo (GLP), da cerâmica vermelha, de produtos da cesta básica, da indústria têxtil, calçadista, vestuário, informática e produtos da cesta básica, de acordo com o Decreto n. ${ }^{\circ}$ 1.867/2018.

Diante disso, o chefe de gabinete da presidência da ALESC emitiu o oficio "Aumento da carga tributária: resumo executivo" aos gabinetes parlamentares justificando que os Decretos n. ${ }^{\circ} 1.860 / 2018$, n. ${ }^{\circ} 1.866 / 2018$ e n. ${ }^{\circ} 1.867 / 2018$ do Poder Executivo prejudicavam a economia catarinense e expressando a necessidade de revogá-los, pois implicariam um "aumento da carga tributária". Argumentava ainda que o "momento para mexer nos benefícios é totalmente impróprio" e que muitas das indústrias que se instalaram em Santa Catarina "agora retornarão para seus Estados e venderão para SC com ICMS de 12\% que será arcado pelo Erário catarinense" (ALESC, 2019d).

Correlativamente, a Federação dos Trabalhadores nas Indústrias da Construção e do Mobiliário do Estado de Santa Catarina (Feticomsc), a Federação dos Trabalhadores Metalúrgicos do Estado de Santa Catarina (Fetimesc) e a 
Federação dos Trabalhadores nas Indústrias da Alimentação do Estado de Santa Catarina (Fetiaesc) também encaminharam ofícios aos parlamentares catarinenses de "manifestação de apoio" pela revogação dos decretos que cancelavam isenções. A Federação do Comércio de Bens, Serviços e Turismo de Santa Catarina (Fecomércio), a Intersindical, o Sindicato das Empresas de Comércio Exterior do Estado de Santa Catarina (Sinditrade), o Sindicato dos Despachantes e Ajudantes Aduaneiros de Santa Catarina (Sindaesc), o Sindicato das Indústrias de Fiação e Tecelagem de Blumenau (Sintex), a Federação das Empresas de Transporte de Carga e Logística no Estado de Santa Catarina (Fretrancesc), a Associação Comercial de Itajaí (Acii), a Associação Comercial e Industrial de Chapecó (Acic), o Sindicato das Contabilidades de Rio do Sul e do Alto Vale (Sindicont), o Sindicato das Agências de Navegação Marítima e Comissárias de Despachos do Estado de Santa Catarina (Sindasc), a Associação Empresarial de São Francisco do Sul (Acisfs), a Superintendência do Porto de Itajaí, a Prefeitura Municipal de Itajaí (PMI) e a Organização das Cooperativas de Santa Catarina (Ocesc) assinaram nota em conjunto de proposta de emenda substitutiva ao Projeto de Lei n. ${ }^{\circ}$ 174/2019, apresentando a necessidade de convalidação e reinstituição dos benefícios fiscais (COMITÊ DE DEFESA DA ECONOMIA CATARINENSE, 2019). Em suma, essas são manifestações das federações patronais e de trabalhadores pela manutenção dos benefícios fiscais do ICMS.

Assim que abriram os trabalhos legislativos, foram apresentados duas Propostas de Sustação de Ato (PSA) e um Projeto de Lei (PL) para anular e/ou adiar a revogação da retirada dos benefícios que entraria em vigor a partir do dia

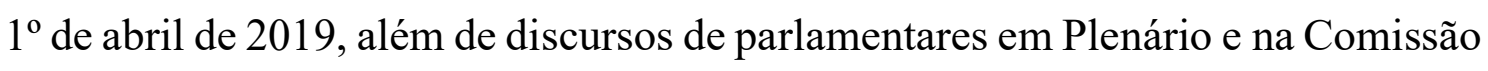
de Finanças e Tributação e matérias jornalísticas com entrevistas de empresários e trabalhadores dizendo que tal medida levaria ao aumento de preços para o consumidor final. Ao final, após reunião dos líderes partidários, foi aprovado o Projeto de Lei n. ${ }^{\circ}$ 24.9/2019, de autoria de deputados de todas as bancadas partidárias, suspendendo os efeitos dos Decretos n. ${ }^{\circ} 1.866 / 2018$ e n. ${ }^{\circ} 1.867 / 2018$ até o dia 31 de julho de 2019.

Um dos objetivos dessas duas medidas é cumprir os limites estabelecidos pela LDO, aprovada em agosto de 2018, que prevê redução gradual da renúncia fiscal de 2019 até 2022, fixando o limite máximo de $16 \%$ da receita bruta de impostos, hoje próximo aos 25\%. Todavia, a Federação da Agricultura e Pecuária 
do Estado de Santa Catarina (FAESC), dentre outras, reivindicou ao governador a revogação do decreto que tributou os agrotóxicos. Federações patronais do comércio, da indústria, da agroindústria e de trabalhadores entraram em campo. Por pressão política de grupos econômicos representados por suas federações, 0 Projeto de Lei n. ${ }^{\circ}$ 24.9/2019 foi convertido na Lei n. ${ }^{\circ} 17.720 / 2019$, revogando dispositivo que fixava o limite máximo da renúncia de receita em $16 \%$ da receita bruta de impostos.

Diante desses dois decretos, o Secretário de Estado da Fazenda foi convocado ao parlamento catarinense para explicar os decretos que revogavam benefícios fiscais concedidos a produtos e setores produtivos do Estado. Bombardeado por parlamentares em sua explanação, o Secretário afirmou que os benefícios fiscais do ICMS, entre 2003 e 2017, "eram concedidos quase todo dia como pão quente", mediante apenas decretos do Executivo, sem lei estadual. Com 11.145 empresas que não pagam ICMS querendo permanecer nesta condição, o lobby político e o poder econômico estão pressionando o Poder Executivo e o Legislativo para mantê-las nesta situação (ALESC, 2019c).

O Secretário da Fazenda destacou também que os créditos tributários concedidos às empresas fazem com que o Estado tenha dívidas milionárias com setores já beneficiados por isenções. Declarou ainda que nem ele sabe quais são todas as empresas e setores beneficiados pela isenção do ICMS, porque existem "incentivos de gaveta”: “(...) eu não conheço todos os benefícios concedidos, não conheço. Porque temos os famosos benefícios que chamamos de gaveta, que não consigo. Então quando removo, alguém 'pia', aí eu sei que o benefício existe" (ALESC, 2019c, p. 7).

Como desdobramento da audiência com o Secretário da Fazenda, em 6 de março de 2019 foi protocolado o requerimento com o pedido de instalação da Comissão Parlamentar de Inquérito (CPI) na Assembleia Legislativa para investigar a concessão de benefícios fiscais por parte da Secretaria de Estado da Fazenda. Com 22 assinaturas, o pedido foi encaminhado para ser analisado pela Procuradoria Geral da Assembleia Legislativa. Com base na manifestação da Procuradoria, o Presidente da ALESC tem a prerrogativa de decidir se acata ou não o requerimento para instalação da CPI. No entanto, o pedido de instalação do CPI ainda se encontra no gabinete da presidência para o despacho (ALESC, 2019b). 
O poder político e econômico também venceu ao derrubar a Medida Provisória (MP) n. ${ }^{\circ}$ 220/2018, que revogava isenções de grandes grupos. Durante o período de tramitação da MP na Assembleia Legislativa, o Secretário da Fazenda recebeu empresários de grupos como Havan, Renner, Karsten, Flamingo, Loghaus e Britannia e ouviu pedidos para que o governo revogasse a MP n. ${ }^{\circ}$ 220/2018. Na reunião, um dos empresários fez declarações mais fortes e disse que empresas poderiam começar a demitir na semana seguinte caso o governo não revisse a medida. Segundo o Secretário, cinco redes passariam a recolher $\mathrm{R} \$ 58$ milhões por ano, que antes não eram pagos por causa de políticas tributárias de seus antecessores. Tanto no caso dos Decretos n. ${ }^{\circ} 1.866 / 2018$ e n. ${ }^{\circ} 1.867 / 2018$ quanto na MP n. $^{\circ}$ 220/2018, os deputados não permitiram revogar isenções fiscais do ICMS (DIÁRIO CATARINENSE, 2018). ${ }^{4}$

Por pressão do TCE/SC e do MP/SC, o Poder Executivo publicou o Decreto n. ${ }^{\circ} 15 / 2019$, o qual instituiu um grupo de trabalho com vistas à adoção de medidas para analisar e propor a concessão ou revogação de benefícios fiscais no Estado e assegurar à sociedade catarinense transparência acerca dos benefícios. Em abril de 2019, foi assinado o Acordo de Cooperação Técnica n. ${ }^{\circ}$ 03/2019 entre o TCE/SC e a $\mathrm{SEF} / \mathrm{SC}$, tendo como objetivo resolver a questão do acesso às informações da renúncia de receita, contudo é necessário aguardar a efetiva operacionalização do acordo. Paralelamente, o MP/SC entrou com uma Ação Direta de Inconstitucionalidade (ADI) declarando a inconstitucionalidade do parágrafo único do art. n. ${ }^{\circ} 99$ da Lei Estadual n. ${ }^{\circ} 10.297 / 1996$, que autorizava a homologação tácita, pelo Poder Legislativo, de convênios relativos ao ICMS, celebrados pelo Estado no âmbito do Confaz.

Em função da ADI do MP/SC, das investidas do Supremo Tribunal Federal (STF) no enfrentamento do conflito federativo da guerra fiscal, da decisão política do governo catarinense em reavaliar as isenções das múltiplas estruturas fiscais que formam a macroestrutura do ICMS e do volume significativo que impacta a renúncia na arrecadação, os benefícios estão sendo reavaliados. Por determinação da Lei Complementar Federal n. ${ }^{\circ}$ 160/2017, o governo do Estado de Santa Catarina tem revisto as isenções e encaminhando ao Parlamento a restituição de muitas

\footnotetext{
${ }^{4}$ Por outro lado, não houve questionamentos sobre a MP n. ${ }^{\circ} 224 / 2019$, que instituiu o Programa Catarinense de Recuperação Fiscal de 2018 (Prefis/SC-2018), o qual perdoava multas e juros de empresas que estavam com o imposto atrasado. Foi concedido desconto de até $90 \%$ de juros e multas, permitindo aos empresários regularizarem sua situação fiscal perante o Estado.
} 
delas, a exemplo dos Projetos de Lei n. ${ }^{\circ} 81.7 / 2019$ e n. ${ }^{\circ}$ 174/2019, que restituem os benefícios do setor siderúrgico, da indústria automobilística, do setor fármaco, da indústria de eletrodomésticos, da indústria alimentícia, dentre outros.

Por determinação do Confaz e ADI do MP/SC, até o dia 31 de julho de 2019 todos os convênios que foram homologados tacitamente necessitam de aprovação legislativa. Para tanto, a Comissão de Finanças e Tributação e o Comitê de Defesa da Competitividade do Produto e Serviço Catarinense, que reúne mais de 20 entidades empresariais, vão trabalhar em conjunto na regulamentação de incentivos concedidos pelo Estado a vários segmentos econômicos. O Comitê enviou um ofício relatando os impactos gerados em face do projeto sobre os incentivos fiscais, manifestando preocupação com a possível revogação (ALESC, 2019a).

O documento entregue aos deputados destaca um estudo realizado pela Federação de Indústrias de Santa Catarina (Fiesc) demonstrando que os incentivos fiscais não causam prejuízo, mas promovem o desenvolvimento do Estado. Na ocasião, a Associação de Usuários dos Portos da Região Sul (Usuport.Sul) apresentou proposta de emenda ao Projeto de Lei n. ${ }^{\circ}$ 174/2019 para assegurar às suas entidades, que reúnem exportadores e importadores, incentivos fiscais concedidos ao longo da últimas décadas. A entidade de classe pediu aos parlamentares catarinenses apoio político para a revogação dos Decretos n. ${ }^{\circ}$ 1.866/2018 e n. ${ }^{\circ}$ 1.867/2018, que cancelam isenções do ICMS (USUPORT.SUL, 2019)..$^{5}$

Fica evidente, portanto, que a macroestrutura fiscal do ICMS é um sistema complexo de incentivos por conseguir múltiplas estruturas de isenção do imposto. Todas as estruturas unitárias (anistia, remissão, subsídio, crédito presumido, isenção, alteração de alíquota ou modificação da base de cálculo, dentre outras modalidades) e programas (Prodec, Pró-Emprego, Pró-Náutica, Pró-Cargas, dentre

\footnotetext{
5 Correlativamente, a Fiesc publicou o documento "Incentivos à economia: mitos e verdades", argumentando que o "(...) Estado, ao conceder os chamados incentivos e benefícios fiscais, está praticando uma RENÚNCIA FISCAL. Em realidade, de forma indireta, está fazendo um INVESTIMENTO SOCIAL em favor de sua população, dando apoio à atividade econômica e, em consequência, mantendo ou criando empregos, possibilitando cada vez mais o seu desenvolvimento e o bem-estar de todos. Retirar ou reduzir tais investimentos será um retrocesso, que fatalmente atingirá e encolherá a atividade econômica, diminuindo a possibilidade de competitividade das empresas e em consequência diminuindo a produção e comercialização de bens e, inclusive, provocando a diminuição de arrecadação de impostos. E mais grave, marginalizando a população com o aumento do desemprego, ao invés de geração de postos de trabalho" (FIESC, 2019, p. 5).
} 
outros) constituem uma rede integrada de processos econômicos e relações políticas sociais que possui uma dinâmica própria de se relacionar com o processo de acumulação. Ao mesmo tempo, essas estruturais fiscais autônomas e independentes se articulam em uma única unidade do imposto do ICMS, formando uma macroestrutura fiscal.

A macroestrutura fiscal do ICMS, enquanto sistema complexo com múltiplas estruturas fiscais, é movida por interesses de grupos econômicos e políticos dentro das instituições estatais de poder. Ademais, no movimento da guerra fiscal, o Estado de Santa Catarina (Lei n. ${ }^{\text {o } 7.547 / 1989}$, art. n. ${ }^{\circ}$ 96, e Lei n. ${ }^{\circ}$ 10.297/1996, art. n. ${ }^{\circ}$ 43) está autorizado a tomar medidas necessárias para elevar quantitativamente a isenção da macroestrutura fiscal do ICMS para a "proteção dos interesses da economia catarinense".

\section{A macroestrutura fiscal do ICMS na formação das desigualdades regionais em Santa Catarina}

Se, por um lado, temos a guerra fiscal entre Unidades da Federação, por outro temos também as disputas regionais dentro de cada uma das 27 Unidades. Para amenizar esse desequilíbrio interno, há programas específicos para fomentar as regiões com menor grau de complexidade econômica. Em nível nacional, há a Superintendência de Desenvolvimento do Nordeste (Sudene) e a Superintendência de Desenvolvimento da Amazônia (Sudam). Em nível estadual, em Santa Catarina, as empresas que, por intermédio do Prodec, optarem por investir nas regiões com menor Índice de Desenvolvimento Humano (IDH) terão um incentivo maior do que se optarem por se instalar numa região de maior complexidade.

Em Santa Catarina, como no Brasil, historicamente a política de desenvolvimento regional é dependente dos dispêndios públicos. Nos estudos sobre a política regional catarinense, há uma predominância de pesquisas acadêmicas que apresentam a macroestrutura fiscal como elemento unificador do território. Ocupar e definir território, acelerar a produção, promover a expansão capitalista no espaço e garantir a reprodução da força de trabalho são ações que se desenvolvem concomitantemente a partir da disponibilidade de meios de financiamento. Nesse caso, o uso dos recursos públicos disponibilizados pela isenção do ICMS acaba criando uma região hegemônica e, por consequência, acirrando o caráter desigual do processo de desenvolvimento capitalista. 
A política de isenção do ICMS cria e recria hierarquias territoriais através da sua distribuição desigual. Ao mesmo tempo que a política estatal transforma e modifica o território, em um movimento da contradição, também destrói promovendo a desterritorialização. Pensar uma política regional é, certamente, deixar para trás o atraso relativo formado por baixo progresso técnico, baixa renda disponível, trabalho sem complexidade e suas desigualdades. O uso fiscal da macroestrutura do ICMS busca solucionar problemas e permitir o livre desenvolvimento das forças produtivas. Mas a forma como se dá a sua distribuição, devido às condições do atraso relativo de determinadas regiões do Estado, é oposta.

No campo da política regional, a situação parecia promissora com a criação das Secretarias de Estado de Desenvolvimento Regional (SDRs). As SDRs pretendiam reverter as desigualdades regionais e explorar os potenciais endógenos da diversa base regional de cada uma das 36 regiões. A criação das SDRs tratou de expor as desigualdades regionais existentes no território, ao considerar que há diferenças nas múltiplas escalas geográficas. Contudo, longe de se preocupar com uma efetiva política de desenvolvimento regional, as distribuições dos incentivos da macroestrutura fiscal do ICMS permaneceram concentradas nas regiões de Itajaí, Joinville e Florianópolis, justamente as que apresentam maior divisão social do trabalho (GOULARTI, 2014).

Com 1,13\% do território nacional, 6,10\% do Valor da Transformação Industrial (VTI) e 4\% do Produto Interno Bruto (PIB) nacional, como poucos Estados da federação, Santa Catarina apresenta como característica uma estrutura produtiva especializada em vários setores, sendo que cada microrregião possui uma especialização. Porém a distribuição regional da isenção fiscal do imposto no território é desigual. Três regiões representam 52,20\% das isenções do imposto. Ampliando para cinco regiões, elas são responsáveis por 70,15\% (ALESC, 2018b). 
Tabela 2 - Distribuição regional da macroestrutura fiscal - Santa Catarina (R\$ milhões, preço constantes)

\begin{tabular}{lrr}
\hline \multicolumn{1}{c}{ Gerência Regional da Fazenda } & Valor da Renúncia & Participação \\
\hline Itajaí & 1.240 .051 & 20,92 \\
Joinville & 1.067 .260 & 18,00 \\
Blumenau & 787.295 & 13,28 \\
Chapecó & 547.874 & 9,24 \\
Joaçaba & 516.449 & 8,71 \\
Florianópolis & 427.144 & 7,21 \\
Criciúma & 260.930 & 4,40 \\
Rio do Sul & 232.445 & 3,92 \\
Tubarão & 202.841 & 3,42 \\
São Miguel do Oeste & 156.979 & 2,65 \\
Porto União & 139.175 & 2,35 \\
Curitibanos & 118.262 & 1,99 \\
Mafra & 97.769 & 1,65 \\
Araranguá & 82.832 & 1,40 \\
Lages & 50.950 & 0,86 \\
\hline Total & $\mathbf{5 . 9 2 8 . 2 5 6}$ & $\mathbf{1 0 0}$ \\
\hline Fonte: Lei Orça
\end{tabular}

Fonte: Lei Orçamentária Anual, 2018.

Essa demonstração significa dizer que o desenvolvimento regional no Estado se concentra em pontos muito seletivos do território. Assim fica posta a seguinte questão: não se pode afirmar que os valores renunciados pelas referidas regiões se reflitam em benefício socioeconômico a todos os municípios e regiões do Estado. Portanto, é preciso tomar cuidado na análise da política fiscal de incentivo para não aceitar de imediato como verdade e com entusiasmo excessivo que o incentivo é fator preponderante para o desenvolvimento regional. Ademais, $68,63 \%$ dos incentivos que constituem a macroestrutura fiscal estão concentrados na faixa litorânea do Estado.

Destarte, o maior benefício em valor foi o crédito presumido nas saídas de artigos têxteis, de vestuário, de artefatos de couro e seus acessórios, que correspondeu a $19,74 \%$ de toda a renúncia de receita informada, seguido dos produtos resultantes do abate de gado bovino, aves e suínos, com $11,60 \%$, crédito presumido nas saídas subsequentes de mercadorias importadas do exterior, com $11,23 \%$, isenção nas saídas de insumos agropecuários, com 6,47\%, redução da 
base de cálculo dos produtos da cesta básica, ${ }^{6} \operatorname{com} 5,33 \%$ e crédito presumido para a produção de leite e derivados in natura, longa vida e em pó, com 5,17\% (ALESC, 2018a).

No caso de sua distribuição regional, tem a divisão social do trabalho como princípio que, em vez de homogeneizar o grau de desenvolvimento, acaba produzindo heterogeneidade, tensionando a problemática regional. Seguindo esse princípio, o que se visualiza é a construção de um processo de desenvolvimento desigual na geração de valor, riqueza e oportunidades. Enquanto um território é valorizado, outro é desvalorizado. Vista dessa forma, a distribuição regional desigual de vantagens econômicas pela macroestrutura fiscal em Santa Catarina gera um processo de exclusão social de regiões e pessoas dos louros do desenvolvimento, o que, por sinal, faz parte da história do sistema capitalista.

Os incentivos possibilitam a expansão geográfica do mercado, reduzem os custos de realização e circulação das mercadorias e ajudam a criar novos espaços para a acumulação. Todavia, da forma com que a macroestrutura fiscal mantém-se centralizada em poucas regiões e cidades, há maior concentração e centralização da riqueza nestes mesmos lugares. À medida que regiões já complexas vão concentrando maior parcela dos incentivos, mais assimétrica será a distribuição regional da macroestrutura fiscal do ICMS. Ou seja, as regiões que apresentam maior grau de acumulação tendem a reforçar sua posição dentro do Estado, confirmando uma tendência da distribuição geográfica das isenções fiscais. Assim, a geografia criada pelo capitalismo também é vista como um lugar de contradição e tensão, e não como expressão de equilíbrio. Por isso a importância de refletir a respeito da política de incentivos fiscais dentro do contexto da literatura do desenvolvimento desigual.

Nesse ponto, a isenção do ICMS acaba promovendo um conjunto de desvinculações constitucional e infraconstitucional de receita vinculada aos municípios, à manutenção dos serviços públicos de saúde e às atividades educacionais. Dos $\mathrm{R} \$ 5,92$ bilhões renunciados em 2018 pelo dispositivo constitucional, 25\% desse valor pertencem aos municípios, isto é, eles deixaram de receber R \$1,46 bilhões somente em 2018. Quanto a essa desvinculação cumpre destacar que, dos 295 municípios catarinenses, 108 possuem população de até 5

\footnotetext{
${ }^{6}$ A lei estadual n. ${ }^{0} 17.737$ de 06/06/2019 trouxe uma nova relação de itens que compõem a cesta básica, reduzindo de 19 tipos de itens para 7 .
} 
mil habitantes. Diante dessa sistemática, além de as múltiplas estruturas fiscais do ICMS contemplarem principalmente as regiões situadas na faixa litorânea, acabam prejudicando as regiões extremas do Estado. Por conseguinte, temos um processo de desenvolvimento desigual e injusto na renúncia do imposto do ICMS.

Não obstante, em 2003, quando as SDRs foram instituídas, 10 municípios catarinenses concentravam $45,9 \%$ da riqueza estadual. Na sua justificativa, a descentralização da estrutura administrativa do Estado pretendia estimular o desenvolvimento regional desconcentrando o PIB. Todavia, dez anos depois, os dados apresentados pelo IBGE apontam para uma maior concentração econômica, $50,51 \%$. Na ponta inversa, os 10 municípios mais pobres que, em 2003, centralizavam $0,20 \%$ do PIB estadual, passaram a concentrar $0,10 \%$. Enquanto os 10 municípios que ocupam o topo da tabela aumentaram em 9,91\% na sua participação no PIB, os 10 municípios da ponta inversa decaíram 50\% (GOULARTI, 2014).

De modo geral, entre os anos de 2002 e 2014, a macrorregião da Grande Florianópolis e, especialmente, a macrorregião do Litoral Norte, elevaram ainda mais sua participação no PIB estadual, respectivamente de $13,71 \%$ para $14,01 \% \mathrm{e}$ de $39,71 \%$ para $45,51 \%$. As outras seis macrorregiões tiveram perda de participação no período. Hoje $70 \%$ do PIB estadual concentra-se na faixa litorânea. A previsão do governo estadual é que em 2030 suba para 75\%, e em 2050 para $85 \%$. Via de regra, a distribuição desigual dos incentivos do ICMS corrobora o processo de concentração e centralização da riqueza (SANTA CATARINA, 2018; ALESC, 2019b).

As isenções das múltiplas estruturas fiscais que constituem a macroestrutura do ICMS estão aquém das expectativas de estabelecer um desenvolvimento simétrico entre as regiões catarinenses. Não vivenciamos um desenvolvimento "utopiense" de Thomas Morus, em que as 54 cidades da ilha da Utopia vivem em perfeita harmonia e igualdade entre si. Logo, passa-se a exigir do poder público estadual medidas mais enérgicas do que as que vêm sendo tomadas. 


\section{Desmistificando a macroestrutura do ICMS na formalização do mercado de trabalho catarinense}

Uma das retóricas do setor empresarial é que incentivo fiscal é sinônimo de desenvolvimento econômico, formalização do mercado de trabalho e geração de renda. Essa concepção está no centro da visão da economia que prevalece em nossa época. Como o incentivo se traduz na realização de lucro, é natural que se empregue à ideia um sentido positivo. Vejamos: "O dono da Havan, Luciano Hang, fez declarações mais fortes e disse que empresas podem começar a demitir na semana que vem caso o governo não revise a medida" (DIÁRIO CATARINENSE, 2018). A multinacional Mead Johnson Nutrition, que se instalou em Itajaí em 2010, produzindo as linhas de Sustagen e Sustegen Kids, também ameaçou deixar Itajaí por mudança na política de incentivos fiscais e ir para Minas Gerais ou Goiás, onde terão incentivos (DIÁRIO CATARINENSE, 2019).

Essa declaração se refere ao lobby político de grupos econômicos com a SEF/SC pela revogação total dos dispositivos estabelecidos pela MP n. ${ }^{\circ}$ 220/2018, que tratava de revogar parcialmente o imposto de ICMS de algumas empresas situadas em território catarinense. ${ }^{7}$ Diante dessa declaração extraída do jornal Diário Catarinense $(2018 ; 2019)$, podemos considerar que a forma de utilização do incentivo fiscal pelo capitalista é condição sine qua non que determina a formalização do mercado de trabalho?

No primeiro trimestre de 2012 havia 236 mil trabalhadores catarinenses trabalhando sem carteira assinada no Estado, para uma renúncia fiscal de $\mathrm{R} \$ 4,87$ bilhões. No último trimestre de 2018, a renúncia fiscal subiu para $\mathrm{R} \$ 5,80$ bilhões (+19,08\%), e o número de trabalhadores sem carteira assinada elevou-se a 266 mil, crescimento de $25,47 \%$. Por esses dados, podemos dizer que não existe uma relação automática entre incentivo fiscal da macroestrutura do ICMS e formalização do emprego. A isenção fiscal em tempos de crise para manter os empregos não se realizou (ALESC, 2018a; IBGE, 2019).

\footnotetext{
${ }^{7}$ Paralelamente à MP n. ${ }^{\circ}$ 220/2018 temos a MP n. ${ }^{\circ}$ 216/2017, a MP n. ${ }^{\circ} 217 / 2017$, a MP n. ${ }^{\circ} 224 / 2018$ e a MP n. ${ }^{\circ} 225 / 2018$. Todas elas tratam de perdoar juros e multas de débitos fiscais na ordem de $\mathrm{R} \$ 218,5$ milhões. As quatro MPs apresentam como justificativa estimular a regularização de débitos tributários de difícil cobrança. Trata-se, assim, de um convite à inadimplência de empresas e grandes contribuintes que sabem que, por esse histórico, sempre poderão contar com refinanciamento de suas dívidas.
} 


\section{Gráfico 1 - Pessoas de 14 anos ou mais de idade desocupadas na semana de referência}

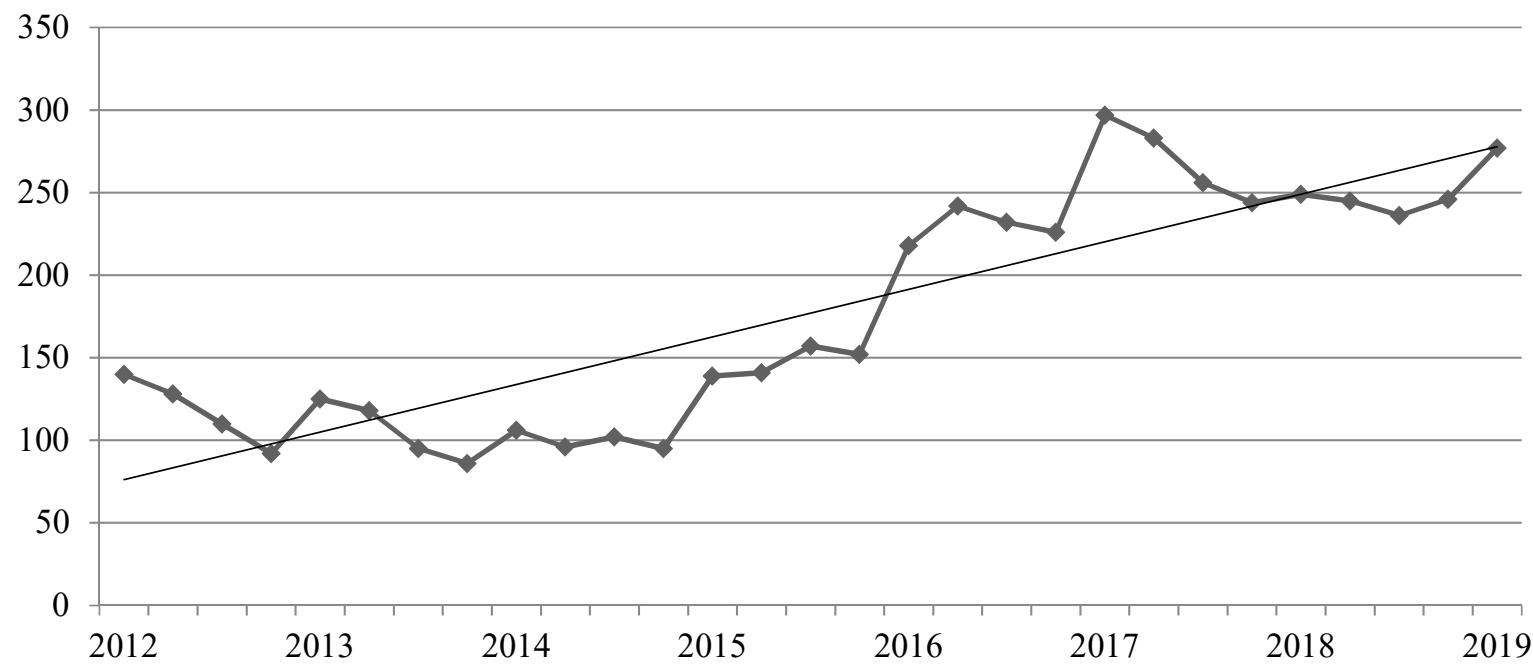

Fonte: IBGE, Diretoria de Pesquisas, Coordenação de Trabalho e Rendimento, Pesquisa Nacional por Amostra de Domicílios Contínua.

Partindo dessa constatação, o que se observa é que as isenções do imposto que formam a macroestrutura fiscal do ICMS são um instrumento que o capitalista utiliza para reduzir custos de produção e elevar a taxa de lucro. Os incentivos carregam o lucro operacional das empresas, sejam elas pequenas, médias ou de grande porte, e valorizam o valor do capital. A macroestrutura do ICMS na qual se processam as decisões capitalistas é um impulso para ampliar a acumulação interna de lucros, sem necessariamente elevar a taxa de investimento e causar a elevação do progresso técnico, nos princípios de Celso Furtado.

Nessa mesma linha de raciocínio, há outro questionamento a se fazer: a expansão quantitativa (Tabela 1) do incentivo do ICMS tem elevado a renda média do trabalhador catarinense? O rendimento médio do trabalhador catarinense $\left(1^{\circ}\right.$ trimestre de 2012) foi de $\mathrm{R} \$ 1.025,00$ e a renúncia fiscal de $\mathrm{R} \$ 4,87$ bilhões. No último trimestre de 2018, a renda média foi de $\mathrm{R} \$ 1.534,00$ (+49,55\%) e a renúncia $\mathrm{R} \$ 5,80$ bilhões $(+19,08 \%)$. Em sete anos a renda média do catarinense oscilou, mas ao final apresentou taxa de crescimento positiva. Porém, deflacionando a renda média pelo Índice Nacional de Preços ao Consumidor Amplo (IPCA), em termos reais, ela cresceu 7,73\%; registre-se, fruto das negociações coletivas do Salário Mínimo Regional. Portanto, averígua-se que o incentivo não tem relação direta (causa e efeito) com o crescimento da renda média do trabalhador, como 
canonizado pela retórica empresarial e beatificado pelo pensamento comum (ALESC, 2018a; IBGE, 2019).

Embora a renda domiciliar per capita média do catarinense seja 25,90\% superior à renda média do País e ocupe a $4^{\mathrm{a}}$ posição entre os Estados, a isenção do ICMS não é sinônimo direto de melhoria na renda do trabalhador. Quanto a isso, é importante destacar que a renda média do catarinense é superior à nacional devido ao Estado possuir o Salário Mínimo Regional, que é superior ao Mínimo Nacional. Mesmo assim, em tempos de crise econômica expande-se as isenções do imposto ao passo que se assiste à retirada de direitos sociais e garantias fundamentais conquistados pela classe trabalhadora.

Cabe observar que o rendimento domiciliar per capita da macrorregião do Meio-Oeste (formada por 55 municípios) estava 16,68\% abaixo da média estadual, o da macrorregião do Planalto Serrano (18 municípios) 25,17\%, o da macrorregião do Litoral Sul (47 municípios) 12,35\%, o da macrorregião do Planalto Norte (13 municípios) 4,56\%, o da macrorregião do Alto Vale do Itajaí (31 municípios) 20,89\% abaixo da média estadual e o da macrorregião do Oeste de Santa Catarina (76 municípios) 14,29\%. Por outro lado, o rendimento da macrorregião do Litoral Norte (42 municípios) estava acima da média estadual, assim como o da macrorregião da Grande Florianópolis (13 municípios). Registre-se que esta última possui o maior rendimento domiciliar per capita do Estado (SANTA CATARINA, 2018). ${ }^{8}$

A partir desse quadro de referência, o empresário não procura reverter os benefícios fiscais do ICMS usufruídos ampliando a renda média do trabalhador catarinense. A isenção fica retida em seus lucros sem que haja elevação dos salários e formalização do mercado de trabalho. No entanto, a redistribuição das múltiplas estruturas fiscais de isenções que formam a macroestrutura do ICMS com elevação da renda em favor dos trabalhadores desencadearia, por seu lado, uma série de reações, tendentes a elevar custos de produção e a reduzir a taxa de lucro.

\footnotetext{
${ }^{8}$ Das pessoas em situação de pobreza do Estado, 9,97\% residem na macrorregião da Grande Florianópolis, $25,48 \%$ residem na macrorregião do Litoral Norte, 4,48\% na macrorregião do Alto Vale do Itajaí, $15,97 \%$ na macrorregião do Litoral Sul, 9,59\% na macrorregião do Planalto Serrano, 7,69\% macrorregião do Planalto Norte, $9,58 \%$ na macrorregião do Meio-Oeste e $15,98 \%$ macrorregião do Oeste (SANTA CATARINA, 2018).
} 
Gráfico 2 - Rendimento médio do trabalho principal, habitualmente recebido por mês, por pessoas de 14 anos ou mais de idade, ocupadas na semana de referência, com rendimento e trabalho, como empregadas no setor privado sem carteira de trabalho assinada (exclusive trabalhador doméstico)

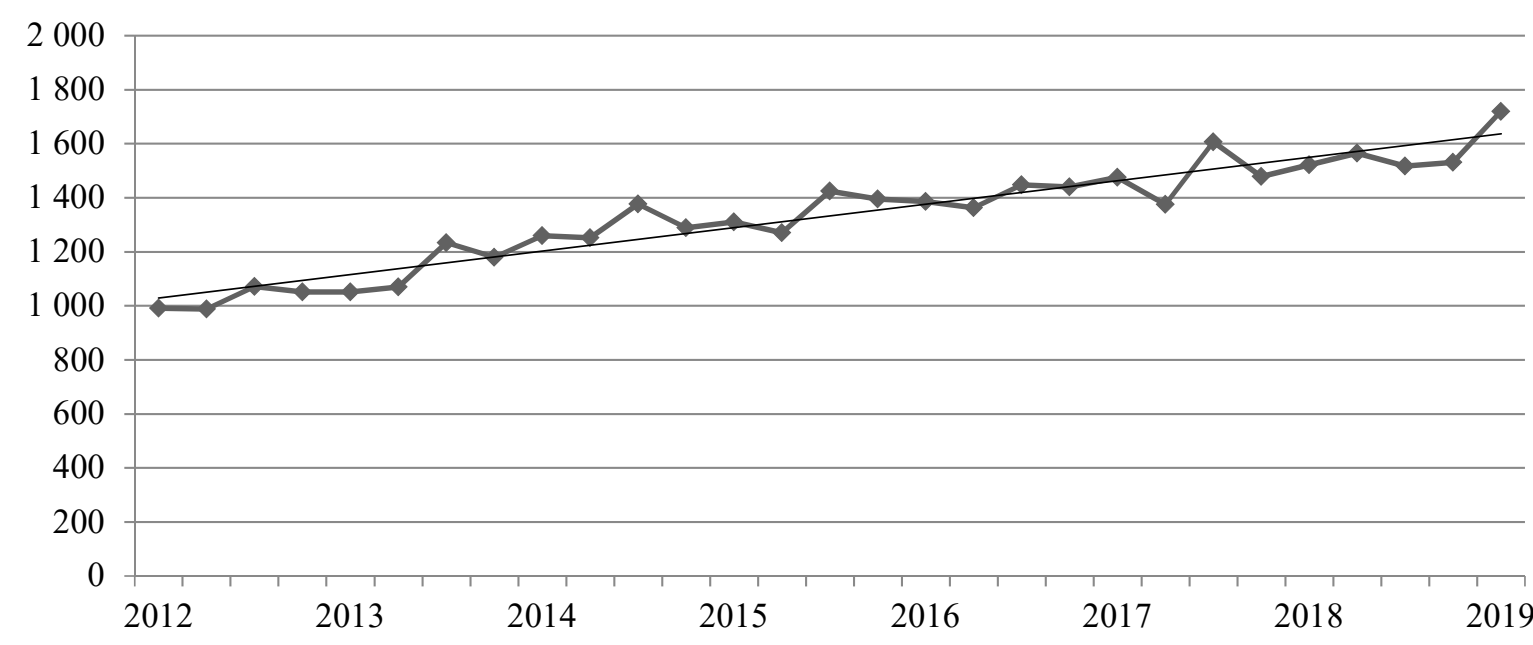

Fonte: IBGE, Diretoria de Pesquisas, Coordenação de Trabalho e Rendimento, Pesquisa Nacional por Amostra de Domicílios Contínua.

O incentivo não é um dispositivo automático (do tipo interruptor) que leva o empresário a gerar novos postos de trabalho. Por exemplo: a taxa de desemprego em Santa Catarina no último trimestre de 2012 era de 2,70\% e a renúncia fiscal, no ano, de R $\$ 4,87$ bilhões. Em 2018, a renúncia ofertada pela macroestrutura fiscal foi para $\mathrm{R} \$ 5,80$ bilhões e a taxa de desemprego esteve em $6,50 \%$, ou seja, o incentivo estadual não apresenta relação direta com a criação de postos de trabalho no setor privado (ALESC, 2018a; IBGE, 2019).

A redução do custo de mão de obra decorrente da isenção do ICMS aumenta a margem de lucro das empresas beneficiadas, mas não garante que elas elevem o estoque de empregos. Os Gráficos 1 e 2, assim como o Gráfico 3, a seguir, mostram que os efeitos da macroestrutura fiscal do ICMS sobre a formalização do mercado de trabalho em Santa Catarina são motivo de controvérsia.

Nesse caso, a isenção não está sendo utilizada para a realização do investimento privado, fenômeno fundamental do desenvolvimento econômico. $\mathrm{O}$ que tem ocorrido é um uso modificado da renúncia de receita distinto daquele da formação da demanda efetiva keynesiana. O capitalista desvia o incentivo fiscal da finalidade do investimento para ações diversas daquelas dos setores produtivos 
com capacidade de aumento da produtividade do trabalho pela ampliação da oferta de mão de obra e elevação da renda média do trabalhador. Mesmo assim, a retórica empresarial e de trabalhadores de que o incentivo fiscal é sinônimo de investimento, emprego e renda pode ter força política e valor social, mas nem por isso tem validade universal.

Quanto a isso, precisamos entender que o capitalismo é intrinsecamente instável e o investimento é uma variável essencial nas flutuações econômicas. A sustentação de um investimento de longo prazo que seja capaz de manter a demanda efetiva pela via das desonerações do imposto estadual do ICMS não é algo semelhante a um interruptor que ativa uma descarga elétrica acionando o acendimento da lâmpada. Destarte, a ideia do incentivo enquanto determinante do emprego tem estabelecido um fio de solidariedade entre as classes sociais que as contradições econômicas levam a se conflitar.

\section{Gráfico 3 - Taxa de desocupação das pessoas de 14 anos ou mais de idade na semana de referência}

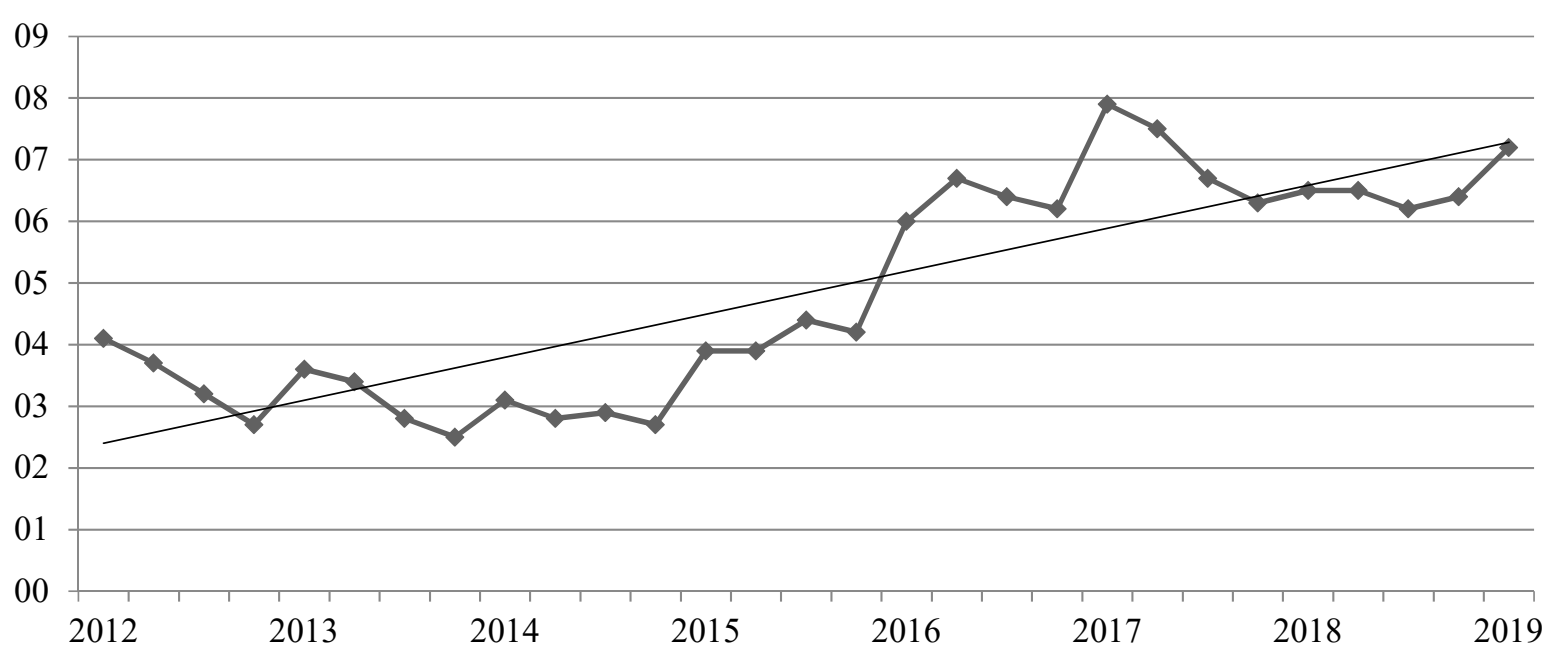

Fonte: IBGE, Diretoria de Pesquisas, Coordenação de Trabalho e Rendimento, Pesquisa Nacional por Amostra de Domicílios Contínua.

Outro dado, talvez ainda mais alarmante, diz respeito ao desemprego oculto. A Taxa de Subutilização da Força de Trabalho para o $1^{\circ}$ trimestre de 2019 chegou a $25 \%$ no conjunto do País, e a $12,10 \%$ em Santa Catarina. Nesses dois casos, a subutilização da força de trabalho foi a maior já registrada ao longo de toda a série histórica da Pesquisa Nacional por Amostra de Domicílios (PNAD) Contínua, que 
teve início em 2012. Com isso, já são 28,3 milhões de brasileiros, dentre os quais 476 mil catarinenses, em condição de desemprego aberto ou oculto (IBGE, 2019).

A política de incentivos fiscais no processo de acumulação de capitais não pode ser explicada mediante uma formulação puramente abstrata. Os desdobramentos da macroestrutura do ICMS na economia catarinense devem ter por fundamento uma base empírica que observe seu desenvolvimento. Uma argumentação pressupõe a existência de problemas cuja solução é motivo de preocupação de algum grupo social. Essa relação do incentivo do ICMS com a manutenção do nível de emprego e formalização do mercado de trabalho não é automática.

Nesse sentido, aqui o paradigma de que o incentivo fiscal é sinônimo de emprego e renda cai por terra. Reduzir custos de produção não significa romper com o "fluxo circular", estabelecendo uma fase de prosperidade. Dessa forma, a política de manutenção do nível de isenção do ICMS, ao garantir a redução de custos de produção e a elevação da taxa de lucro, assegura um processo de acumulação de capitais com reprodução das desigualdades regionais e exclusão social.

\section{Considerações finais}

Ao final deste estudo, considerando a constituição de uma categoria analítica para definir e analisar a política de incentivos fiscais do ICMS, o lobby político de grupos empresariais e de trabalhadores pela manutenção e ampliação das isenções, a problematização da relação da macroestrutura com a política de desenvolvimento regional e a desmitificação de que isenção é sinônimo de emprego e renda (Gráficos 1, 2 e 3), constata-se que há elementos suficientes para sustentar que as isenções do imposto estadual do ICMS são um processo dentro de um movimento contraditório.

As múltiplas estruturas fiscais que constituem a macroestrutura fiscal do ICMS manifestam-se conforme a correlação de forças da categoria luta de classes. Partindo dessa categoria analítica, quem paga mais e quem paga menos impostos e quem se apropria mais ou menos das isenções são disputas que se dão no campo da política e da economia. Se existem frações de classes que se beneficiam da macroestrutura fiscal, há outras que são prejudicadas. 
Dentro do movimento da guerra fiscal, a macroestrutura fiscal do ICMS passou por alterações legislativas, adequações e reestruturações para, assim, incluir novos setores na lista de beneficiados com o pressuposto de estimular e atrair novos investimentos para o Estado. Todavia, o movimento fiscal da macroestrutura está em direção às regiões litorâneas, logo, associando-se a aumentos da concentração econômica nessas regiões. Portanto, analisando a política de incentivos fiscais em Santa Catarina, é possível identificar que a sua distribuição espacial é desigual. Enquanto um território é valorizado, outro é desvalorizado. Vista dessa forma, a distribuição regional desigual de vantagens econômicas pela macroestrutura do imposto estadual gera um processo de exclusão social de regiões (Tabela 2) e pessoas do desenvolvimento.

Outra observação digna de conclusão é que a relação que trata da isenção do ICMS está descolada da formalização do mercado de trabalho e da melhoria da renda do trabalhador catarinense. Assim, pode-se inferir que a macroestrutura fiscal do ICMS está estruturada em dois princípios: i) reduzir custos de produção; e, ii) elevar a margem de lucro. Dentro dos elementos da contradição, sua distribuição segue os preceitos de duas categorias analíticas: i) desenvolvimento desigual; e, ii) divisão social do trabalho. Essas duas categorias permitem compreender que as dinâmicas sociais e econômicas de uma região são resultado de processos conflituosos e contraditórios, os quais ocorrem devido às tendências contraditórias de diferenciação do capital.

Para tanto, a formação de uma macroestrutura fiscal capitalista é um sistema com múltiplas estruturas de remissão do imposto e programas estaduais movidos por interesses econômicos de patrões e trabalhadores dentro das instituições estatais de poder. À medida que cresce o volume de recurso desonerado pelo imposto estadual (Tabela 1), as isenções do ICMS tornam-se, cada vez mais, um componente fundamental na formação da taxa de lucro. Assim, a macroestrutura, ao viabilizar o lucro, está a serviço da realização desse projeto que reflete a relação de forças entre os grupos sociais que compõem o conjunto da coletividade da sociedade catarinense.

Este artigo desenvolveu a ideia de que a macroestrutura fiscal do ICMS é uma política contraditória utilizada pelo Estado de Santa Catarina para dar garantias à reprodução dos negócios e negociatas realizados pelo capital. Com tal perspectiva, a oferta abundante de incentivos das múltiplas estruturas de isenção 
do imposto estadual não é acompanhada de alteração na distribuição de renda em favor dos trabalhadores. Mesmo com um sistema tributário regressivo, sindicatos e federações de trabalhadores se uniram aos patronais para que os benefícios fiscais concedidos ao capital não fossem revogados pelos decretos e leis citados no texto. Dessa forma, em última instância, o que tem se engendrado pela macroestrutura fiscal do ICMS é um processo de superexploração dos recursos públicos estaduais.

Em que pesem essas manifestações de trabalhadores e patrões, na medida em que a política de incentivos fiscais vem sendo desenvolvida pelo governo estadual sem orientação em prol do desenvolvimento econômico (nos princípios definidos por Celso Furtado) e melhoria da qualidade de vida do cidadão, novos e graves problemas tendem a se acumular como, por exemplo, a acentuação das desigualdades regionais e sociais.

\section{Referências}

ALESC - Assembleia Legislativa do Estado de Santa Catarina. ALESC e entidades empresariais vão trabalhar em defesa dos incentivos fiscais em SC. 2019a Disponível em: $<$ http://agenciaal.alesc.sc.gov.br/index.php/noticia_single/alesc-eentidades-empresariais-vaeo-trabalhar-em-defesa-dos-incentivos-fisc $>$ Acesso em 20 jun. 2019.

ALESC - Assembleia Legislativa do Estado de Santa Catarina. Convocação do Secretário da Fazenda pela Comissão de Finanças e Tributação da ALESC. Florianópolis, SC: ALESC, 2019d.

ALESC - Assembleia Legislativa do Estado de Santa Catarina. Diário da Assembleia. Ano LXVIII Florianópolis, 27 de fevereiro de 2019 n. ${ }^{\circ} 7.399 .19^{\mathrm{a}}$ Legislatura, $1^{a}$ Sessão Legislativa. Florianópolis, SC: ALESC, $2019 \mathrm{c}$.

ALESC - Assembleia Legislativa do Estado de Santa Catarina. Oficio Circular n. ${ }^{o}$ 0001/19/CGP. Florianópolis, SC: ALESC, fev. de 2019. $2019 \mathrm{f}$.

ALESC - Assembleia Legislativa do Estado de Santa Catarina. Pedido para instalação da CPI dos Beneficios Fiscais é protocolado. 2019b. Disponível em: $<$ http://agenciaal.alesc.sc.gov.br/index.php/noticia_single/pedido-para-instalacae o-da-cpi-dos-beneficios-fiscais-e-protocolado> Acesso em: 20 jun. 2019.

ALESC - Assembleia Legislativa do Estado de Santa Catarina. Projeto de Lei $n .^{o}$ 97.4/2018: Dispõe sobre as diretrizes orçamentárias para o exercício financeiro de 2019 e estabelece outras providências. Florianópolis, SC: ALESC, 2018a. 84p. 
ALESC - Assembleia Legislativa do Estado de Santa Catarina. Projeto de Lei $n .^{o}$ 246.0/2018: Estima a receita e fixa a despesa do Estado para o exercício financeiro de 2019. Florianópolis, SC: ALESC, 2018b. 1182p.

COMITE DE DEFESA DA COMPETITIVIDADE DA ECONOMIA CATARINENSE. Ofício $n .{ }^{\circ}$ 020/2019. Itajaí, SC: 2019.

DIÁRIO CATARINENSE. Governo de SC nega revogar redução de ICMS para indústria e atacado. 2018. Disponível em: <http://dc.clicrbs.com.br/sc/noticias /noticia/2018/04/governo-de-sc-nega-revogar-reducao-de-icms-para-industria-eatacado-10319705.html> Acesso em: 20 jun. 2019.

DIÁRIO CATARINENSE. Indústria ameaça deixar Itajaí por mudança de incentivos. 2019 Disponível em: $<$ https://www.nsctotal.com.br/colunistas/moacirpereira/industria-ameaca-deixar-itajai-por-mudanca-de-incentivos $>$ Acesso em: 09 jul. 2019.

FIESC - Federação das Indústrias do Estado de Santa Catarina. Incentivos à economia: Mitos e Verdades. Florianópolis, SC: FIESC, 2019. 73p.

GOULARTI, J. G. Desenvolvimento desigual, incentivos fiscais e acumulação em Santa Catarina. Florianópolis, SC: Insular, 2014. 194p.

HENRIQUES, E. F. Os beneficios fiscais no direito financeiro e orçamentário: o gasto tributário no direito brasileiro. São Paulo, SP: Quartier Latin, 2010. 304p.

IBGE - Instituto Brasileiro de Geografia e Estatística. Pesquisa Nacional por Amostra de Domicílios Contínua. Divulgação trimestral, janeiro a março de 2019.

LOPREATO, F. L. Caminhos da política fiscal do Brasil. São Paulo, SP: Unesp, 2013. 279p.

MP-SC - Ministério Público do Estado de Santa Catarina. Ação direta de inconstitucionalidade (ADI) $n .^{\circ}$ 8000014-09.2017.8.24.000. Florianópolis, SC: $\mathrm{MP} / \mathrm{SC}, 2017.166 \mathrm{p}$.

SANTA CATARINA. Plano de Desenvolvimento de Santa Catarina 2030: Plano SC 2030. Florianópolis, SC: Governo do Estado de Santa Catarina, 2018. 177p.

TCE/SC - Tribunal de Contas do Estado de Santa Catarina. Relatório técnico sobre as contas do governo do estado exercício de 2018. Florianópolis, SC: TCE/SC, 2019. 256p. 
USUPORT.SUL - Associação de Usuários dos Portos da Região Sul. Ofício $n .^{\circ}$ 106/2019. Itajaí, SC: Usuport. Sul, 2019. 